\title{
The effect of core competence building on companies performance
}

Citation for published version (APA):

Duysters, G. M., \& Hagedoorn, J. (1996). The effect of core competence building on companies performance. MERIT, Maastricht Economic Research Institute on Innovation and Technology. MERIT Research Memoranda No. 010 https://doi.org/10.26481/umamer.1996010

Document status and date:

Published: 01/01/1996

DOI:

10.26481/umamer.1996010

Document Version:

Publisher's PDF, also known as Version of record

\section{Please check the document version of this publication:}

- A submitted manuscript is the version of the article upon submission and before peer-review. There can be important differences between the submitted version and the official published version of record.

People interested in the research are advised to contact the author for the final version of the publication, or visit the DOI to the publisher's website.

- The final author version and the galley proof are versions of the publication after peer review.

- The final published version features the final layout of the paper including the volume, issue and page numbers.

Link to publication

\footnotetext{
General rights rights.

- You may freely distribute the URL identifying the publication in the public portal. please follow below link for the End User Agreement:

www.umlib.nl/taverne-license

Take down policy

If you believe that this document breaches copyright please contact us at:

repository@maastrichtuniversity.nl

providing details and we will investigate your claim.
}

Copyright and moral rights for the publications made accessible in the public portal are retained by the authors and/or other copyright owners and it is a condition of accessing publications that users recognise and abide by the legal requirements associated with these

- Users may download and print one copy of any publication from the public portal for the purpose of private study or research.

- You may not further distribute the material or use it for any profit-making activity or commercial gain

If the publication is distributed under the terms of Article $25 \mathrm{fa}$ of the Dutch Copyright Act, indicated by the "Taverne" license above, 
The effect of core competence building on company performance

Geert Duysters and John Hagedoorn

May 1996 
MERIT, Faculty of Economics and Business Administration, University of Limburg, P.O. Box 616, 6200 MD Maastricht (Netherlands) - telephone (31)433883897- fax: (31)43-3216518 


\title{
The effect of core competence building on company performance
}

\author{
Summary
}

This paper contributes to the understanding of the importance of dynamic firm capabilities for corporate performance in isolating the effect of core competences on the performance of companies. It discusses and tests the assumed relation between core competences and economic performance, including the effect of the external appropriation of these competences through mergers and acquisitions as well as through strategic technology alliances. A major conclusion is that, particularly in high-tech sectors, a specific set of endogenous technological core capabilities is needed to generate performance differentials. Also, the external appropriation of competences does not seem to be an easy solution through which companies can improve their existing capabilities. 


\section{INTRODUCTION}

In recent years the resource-based theory of the firm (Wernerfelt, 1984 and 1995) and related contributions (e.g. Teece, 1982; Rumelt, 1984; Barney, 1986) focus on the importance of understanding company performance as a result of the efficient use of unique company capabilities that create sustained performance differentials within industries. Similar approaches are found in evolutionary economic theory (Nelson and Winter, 1982) and the theory of dynamic firm capabilities (Nelson, 1991) that analyze inter-firm differentials in terms of strategy, structure and core capabilities. Other recent contributions stress the importance of down-scoping of firms in terms of refocusing of major activities to explain successful corporate performance (Hoskisson and Hitt, 1994; Hoskisson et al, 1994) which we also understand as part of this more general attempt to study the effect of endogenous company capabilities on economic performance.

In the following analysis we will contribute to the understanding of the importance of dynamic firm capabilities for corporate performance in 'isolating' the effect of the creation of 'core competences' on the performance of companies. We stress that it is not the purpose of our analysis to present a general model for understanding company performance differentials. Given this modest objective we can apply a simple model that analyzes performance differences as a result of independent variables that are related to structure, strategy and core capabilities or competences of firms. In particular variables related to strategy and core 
competences are singled out to measure their impact on performance. In that context we define strategies as deliberate policies that companies pursue to improve their performance, following the more or less standard perception of strategy in terms of broad commitments that define both corporate objectives and ways to pursue these objectives.

In the literature the frequent use of the concept of core competences has not always run parallel to the further development of a clear definition. However, gradually the concept is becoming clearer and also more open to operational constructs for empirical research. Hamel and Prahalad (1994) describe core competences as "... a bundle of skills and technologies ..." (p. 202). Markides and Williamson (1994) define core competences as a pool of experience, knowledge, and systems that together can act as catalysts that create and accumulate new strategic assets. These strategic assets, which are imperfectly imitable, constitute a firm's competitive advantage. Following Nelson (1991) core capabilities can be linked to a set of skills and search routines developed within firms. In industries where technological innovation is an important phenomenon these core capabilities of firms are expected to depend largely on skills and routines related to R\&D.

The still somewhat unclear character of the concept of core competences forces us to use operational constructs for core competences through a multidimensional measurement looking at the technological specialization, the innovative input, and the degree of diversification or specialization of companies. 
Our empirical analysis will be restricted to one particular sector, i.e the international data processing industry. Reasons for choosing this sector are the relative abundance of reliable data on a large number of indicators for company performance, structure and strategies, the presence of diversified as well as more specialized companies, and the importance of this sector as a strategic sector in international competition. All this turns this sector into an interesting field for empirical research.

This paper starts off with an overview of major topics in the assessment of the role of several aspects of core competences that create differential company performances. In that particular section we will also introduce a set of five hypotheses, derived from the literature, that will be tested empirically. The next section gives some insight in the model used to measure the effect of core competences, the variables and measures used, as well as a brief description of the population and the data. This is followed by sections in which we present the actual results of the analysis, a discussion of major findings and some conclusions.

\section{EXPECTED EFFECTS OF CORE COMPETENCES ON ECONOMIC}

\section{PERFORMANCE}

In the following we will first discuss the assumed relation between dimensions of core competences and economic performance in terms of the effect of technological specialization, innovative capabilities, and diversification and specialization. In 
addition to this we will reflect on the possible effect of mergers and acquisitions (M\&As) and strategic technology alliances that can be seen as major means of external and quasi-external appropriation of core competences or as means to strengthen existing capabilities (Dunning, 1995; Haspeslagh and Jemison, 1991; Mowery et al., 1995). Because of the cumulative and tacit nature of technological knowledge, which is of particular relevance in so-called high-tech industries (Dosi, 1988; Dosi and Orsenigo, 1988; Nelson and Winter, 1982; Freeman, 1982), we assume that this kind of knowledge is often very difficult to transfer from one company to another and therefore cannot be acquired easily through arms-length transactions (Mowery, 1988; Mowery et al., 1995; Osborn and Baughn, 1990). Both mergers and acquisitions and strategic technology alliances are alternatives to armslength transactions and enter into the arena of core competences if companies choose to externally search for means to cultivate their skills and capabilities further.

For each of these relations, which we will outline in greater detail below, we will present hypotheses.

\section{Technological specialization}

The importance of core competences, through their positive influence on the performance of companies, is frequently related to technological competences, technical skills and knowledge developed within companies (Hamel and Prahalad, 
1994; Markides and Williamson, 1994; Nelson, 1991). Teece et al. (1994) and Robins and Wiersema (1995) point at the importance of coherence in corporate capabilities that strengthen the competitive advantages of companies. Robins and Wiersema (1995) found that multi-business companies with commonalities based on shared capabilities and know-how are associated with higher economic performance. Teece et al. (1994) stress the relevance of corporate coherence based on learning economies, reinforced by path dependencies, for understanding successful performance. Henderson and Cockburn (1994) mention 'idiosyncratic research capabilities' as a major source of strategic competence that have a positive effect on company performance in high-tech industries. A common element that we find in all these contributions is the importance of a proven track record in terms of well-developed skills in related technologies leading to a certain degree of technological specialization.

One of the more frequently used constructs that can help us trace the level of technological specialization of companies is found in patent statistics. Patents are seen as an acceptable indicator for research output and proven technological competence (Patel and Pavitt, 1991; Cantwell and Hodson, 1991). As so many other indicators this one is also subject to a debate regarding its usefulness (Cohen and Levin, 1989; Griliches, 1990; Archibugi, 1992) but it appears to be one of the more appropriate indicators that enable us to compare the technological performance of companies (Pavitt, 1988; Acs and Audretsch, 1989). Patents do indicate whether a 
company has been able to turn its research and other innovative activities into inventions that are worth protecting. In relation to the technological specialization of companies, the concentration of patents in particular areas of industrial activity indicates certain choices with regard to priority skills and concentrated innovative capabilities. In other words, the patent specialization indicator in a major field of a company's activities expresses the established character of core competences and technological specialization in terms of research output and technological skills. Thus,

1 The degree of technological specialization of firms (patent specialization), as an important dimension of core competences, is expected to be positively related to their economic performance.

\section{Innovative capabilities}

The relevance of technological skills for understanding core competences returns in the possible effect of innovative input factors on performance differentials. Studies on the effect of innovation on economic performance mention that technological opportunity frequently acts as an intermediary factor explaining sectoral differences (Dosi, 1984; Cohen et al., 1987; Klevorick, et al, 1995). As we are studying one sector and in particular a high-tech sector we interpret the relationship between innovation, measured in terms of R\&D intensity, and 
economic performance as rather straightforward and positive. For R\&D intensity we assume a positive relationship that expresses a firm's specific innovative capabilities in terms of core competences that are associated with current technological trends in the industry. Hence,

2 The $R \& D$ intensity of firms is positively related to their economic performance.

\section{Diversification and specialization}

The degree of diversification, in particular unrelated diversification, or its reverse the degree of specialization, is expected to be relevant for understanding the role that core competences play in creating performance differentials. The less coherent and related the skills and knowledge within a company, the more difficult it will be to benefit from economies of scope. It has to be stressed that research on diversification has generated a mixed bag of rather contradictory results. However, an increasing number of studies questions the more traditional view that the degree of overall diversification of firms is positively related to their economic performance. Research by Rumelt (1974) and Ramanujam and Varadarajan (1989) suggests that it is difficult to establish a positive relationship between the degree of diversification of companies and their profitability. The recent contribution by 
Hoskisson et al. (1994) indicates that the degree of companies' diversification is related negatively to their economic performance. Other recent research has established that the degree of relatedness of lines of business, which comes closer to specialization in the light of core capabilities, is positively related to the economic performance of diversified firms (Wernerfelt \& Montgomery, 1986; Varadarajan and Ramanujam, 1987; Ramanujam and Varadarajan, 1989; Capon et al., 1988; Harrison et al., 1993). Following these studies we submit that:

3 There exists an inverse relation between the degree of diversification of companies and their economic performance, or put differently, there is a positive relation between the degree of specialization of companies and their economic performance.

\section{Mergers and acquisitions}

As already mentioned in the above M\&As can be seen as instruments used by companies to externally acquire capabilities developed by their partners, as such they can have a positive economic effect on companies that are active in the M\&A market. However, Meeks' (1977) overview of studies on the economic effects of M\&As performed during the late fifties and sixties reveals that there is substantial ex post evidence that mergers and acquisitions have negative effects on the profitability of firms. Meeks' (1977) own empirical research suggests that in general 
there is a negative effect. Ravenscraft and Scherer (1987) demonstrate a negative post-acquisition effect on profitability. Porter (1987) found that about $75 \%$ of the 'unrelated acquisitions' and about $60 \%$ of the 'acquisitions in entirely new industries' he studied were divested after a few years, showing no positive effect on the companies involved. In a study of M\&As by Japanese companies Odagiri and Hase (1989) found little or no evidence that M\&As improved profitability. In particular horizontal M\&As performed poorly. Odagiri and Hase (1989) also found that M\&As that extended existing product-lines had a positive but limited effect on the profitability of firms. Hoskisson and Hitt (1994) state that acquisitions may in general have negative effects on company performance because these acquisitions absorb too much attention from management, they increase debt and they multiply financial controls instead of search for strategic opportunities. However, Hoskisson and Hitt (1994) also suggest that related acquisitions can have a positive effect on company performance if these acquisitions support innovative activities of firms. Therefore,

$4 \quad$ There exists a positive relation between an increasing share of related M\&As in the total number of M\&As of companies and the economic performance of companies. 


\section{Strategic technology alliances}

Strategic technology alliances can be used by companies to absorb new technologies from their partners or to jointly develop new innovative capabilities. Learning through alliances can complement endogenous learning to create new competences (Kogut, 1991; Auster, 1992). The extent to which such strategies are successful is not always clear, for instance Hagedoorn and Schakenraad (1994) found no direct effect of strategic technology alliances on economic performance in general. However, they did establish that in high tech industries research oriented strategic technology alliances are associated with higher economic performance. In the context of the present research an interesting question is to what extent the concentration on strategic technology alliances related to the data processing industry is an effective mechanism for strengthening core competences, or whether the setting up of a wider variety of complementary strategic technology alliances has a more positive effect on company performance. Previous research suggests that complementarity is a major driver of partnering behaviour (Hagedoorn, 1993 and 1995; Harrigan, 1985; Mowery, 1988). This suggests that a strategy aimed at creating a rather broad set of alliances that are complementary to endogenous capabilities could have a more positive effect on company performance than the formation of alliances that parallel existing capabilities. Thus, 
$5 \quad$ There exists an inverse relation between the concentration of strategic technology alliances of companies in one narrow field of their interest and the economic performance of companies.

\section{DESCRIPTION OF THE 'MODEL’, POPULATION AND DATA}

It will be obvious that the main objective of our paper is to single out the effect of core competence building on company performance and not to develop a general model for understanding inter-firm differences in economic performance. This rather modest goal allows us to apply a simple model with core competence-related indicators as key independent variables. However, we also have to acknowledge the role that other variables can play in explaining company performance and as such these have to enter into the equation to concede the complexity of this context.

The general outline of the 'model' for the empirical assessment of the effect of core competence building on company performance is as follows:

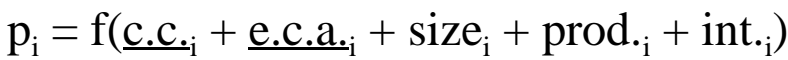

where $\mathrm{p}$ is the economic performance of firms, c.c. are core competences (technological specialization, innovative capabilities, specialization/diversification), e.c.a. are external competence appropriation indicators of M\&As and strategic technology alliances. The other independent variables are size of firms, the level of productivity, and the degree of internationality. As we take the average of value 
1992 and 1993 for the dependent variable and the average value of 1986 - 1991 for the independent variables we introduce a time-lag of several years.

\section{Variables and measures}

Economic performance of each company in our sample is defined as the average operating income to sales ratio for the years 1992 and 1993. It is known that this kind of indicator has certain drawbacks in particular in the context of sectoral differences and a comparison of manufacturing with service industries (Davis and Kay, 1990; Ansoff and McDonnel, 1990). As our present study refers in particular to one industry we can 'control' for such inter-sectoral differences. We use operating income as an alternative to the often used net-income measure because operating income provides a more robust measure for corporate performance than net income ${ }^{1}$ (Rees, 1990).

Core competences are measured by means of three basic indicators: technological specialization, innovative capabilities and specialization/diversification. Combined, these indicators provide an adequate description of the core competences of the various companies in our sample.

As an indicator for technological specialization we use the ratio of the data processing patent applications to total patent applications of each company for the period 1986-1991. We chose US patent office data because we expect the US market to be the most advanced in terms of the combination of competition, 
openness and technological sophistication, in particular in information technology. We took the number of patents that firms applied for in SIC code 357 (computer and office equipment), which not only covers computers in a narrow sense but also includes peripheral equipment, storage devices and terminals. Instead of taking the absolute number of patent applications, as an indicator for the absolute technological strength of companies, we use a relative measure to account for the degree of technological specialization. Ratios close to 1 indicate that companies concentrate their patents mainly in data processing, whereas ratios close to 0 indicate that most of the patents of companies are applied for other fields than data processing.

As an indicator of the innovative capabilities of each firm we apply the 'standard' innovation input measure of $R \& D$ intensity, in this case the data processing $\mathrm{R} \& \mathrm{D}$ expenditures as a percentage of total data processing revenues over the period 1986-1991.

Our third measure of core competences is the specialization ratio of firms, indicating the share of data processing sales in total corporate sales during the period 1986-1991. Values close to 1 indicate that the revenues of companies are almost completely derived from sales of data processing equipment, whereas values close to 0 indicate that the data processing revenues are only a small fraction of a firm's total revenues. 
For external competence appropriation measures we use data on M\&As and strategic technology alliances during the period 1986-1991. Instead of focusing on the total effect of M\&As and strategic technology alliances on economic performance we concentrate on the effect of a specialization of these alliances and M\&As in the field of data processing on corporate performance. The data processing alliances to total alliances ratio and the ratio of data processing M\&As to total M\&As are used to determine the degree of specialization in the external appropriation of competences. Again values close to 1 refer to a specialization of M\&As and strategic technology alliances in data processing whereas values close to 0 indicate that the far majority of their alliances and M\&As can be found outside the field of data processing.

Apart from the measures and variables mentioned above our analysis also includes a number of other indicators not directly related to core competence building. Size of companies is measured by taking the log of the average data processing revenues that companies realized during the period 1986-1991. We have chosen revenues as an indicator instead of the more frequently applied employment indicator to account for quasi-integration. It is well known that Japanese companies have fewer employees than their US and European competitors on account of the Japanese lean production practice and sophisticated customer-supplier networks. However, their size in terms of revenues, which roughly equals turnover, is in our opinion a better indicator of their economic magnitude in comparison with 
companies from other regions. Older literature surveys that cover a large number of studies performed since the 1960s, indicate that there is no direct effect of size of firms on economic performance (Hagedoorn and Schakenraad, 1994). Recent research is somewhat ambiguous. For instance, Robins and Wiersema (1995) also found no significant effect of firm size on economic performance. Contrary to this Hoskisson et al. (1994) did find a positive effect of size on the economic performance of firms. As size of firms is so frequently mentioned in studies, we included the variable size in our analysis because of its possible effect on corporate performance.

Productivity is included in the analysis as we, following a standard economic line of reasoning, expect labour productivity differentials to have a positive effect on the economic performance of companies. As the data processing industry is gradually becoming more mature (IDC, 1988; Malerba et al., 1990; Forester, 1993; Duysters, 1996) we assume that, although Schumpeterian innovative rents will still be important, productivity increases play a significant role in distributing economic performance amongst competitors. In this study, productivity is measured as the data processing employment to data processing sales ratio for each firm during the period 1986-1991.

Internationalization is one of the variables in this study because the literature on internationalization of companies, see Caves (1982) and Dunning (1993) for overviews of studies since the 1970s, suggests that internationalization has a, albeit 
marginally, positive effect on the profitability of firms. Hoskisson and Hitt (1994) state that internationalization, through the combined effects of markets, sourcing, economies of scale and scope, and increasing learning opportunities, has a positive effect on profitability. As an indicator of internationalization of companies during the years 1986-1991 we employ the percentage of sales that were accumulated outside a firm's home region. We distinguish four home regions, i.e. the United States, Europe, Asia/Pacific and others. ${ }^{2}$

\section{Population and Data}

Our analysis refers to a group of 61 companies that together build the core of the international data processing industry. We estimate that these companies together stand for about $75 \%$ of the international data processing industry ${ }^{3}$. Of the 61 companies in our sample, the headquarters of 36 are based in the United States, 7 are European companies, 14 are Japanese and 3 companies are based in Taiwan, 1 company is based in Canada (see Annex I).

Data for the dependent variable (operating income) and independent variables such as data processing $\mathrm{R} \& \mathrm{D}$, sales specialization, size, productivity and internationalization were taken from several issues of Gartner Group's annual Yardstick top 100 worldwide covering a 15 year period (1980-1994). The Yardstick top 100 worldwide is an authoritative statistical review of the information processing industry comprising the top 100 data processing vendors worldwide. 
Data in the Yarstick is updated annually through surveys and research by Gartner Group consultants and industry analysts. When data is missing estimates are taken from industry analyst input and from other available industry sources. These estimates are primarily made for privately held company information. The Yardstick contains calender year information, as opposed to information based upon fiscal years, which allows us to make better comparisons between companies.

The data on patents was taken from the US Patent and Trademark Office database (US Department of Commerce). The data that was made available to us contains data through December of 1993. Data on M\&A specialization was extracted from SRI Securities Data's M\&A database. This data bank is property of the firm Securities Data and can be used via on-line access. Currently it contains information on about 125.000 worldwide M\&As for the period 1980-1994. This information is arranged in several data files. For a limited period of time this data base has been accessed and a specific data sample has been extracted. The relational form of the data base facilitates the linking of these data files to each other and also to files in other data banks. Within the M\&As data base there is information on the year the M\&A got established. In addition, it contains company information on the acquirer, the target, the parent acquirer and the parent target firm. The industry information is provided in SIC codes of the aquiree and acquirer. Unfortunately, the distinction between a merger or an acquisition as made by Securities Data does not always correspond to the actual background of the M\&A. This is partly due to the 
character of information on M\&As in the trade literature. For example, a number of cases has been classified as mergers despite the obvious mismatches in firm-size indicating an acquisition. Acquisitions are frequently presented as mergers because of the negative publicity that acquisitions receive in particular if a foreign partner is involved. Also, the official classification and definition of both modes differs from country to country (Milgrom and Roberts, 1992). As M\&As both lead to integration they are taken together and considered as one single category.

Finally, all the data regarding strategic technology alliances (STA specialization) was taken from the CATI database. The MERIT-CATI data bank contains information on nearly 13.000 cooperative technology agreements involving over 6.000 parent companies. The alliances in the database are primarily related to technology cooperation. Mere production or marketing agreements are therefore excluded. The information on strategic technology alliances in this database covers the period 1970-1994. See Hagedoorn and Schakenraad (1994) for a further description of this data bank.

\section{RESULTS}

In order to test hypotheses 1 to 5 we applied ordinary least square regression (see table 1). This table shows that consistent with hypothesis 1 we find a significant positive relationship between technological specialization in data processing of firms and their economic performance. Hypothesis 2, on the other hand, could not 
be confirmed by our study. Instead of the expected positive effect between R\&D intensity of firms and economic performance we find a negative but statistically not significant relationship between the two variables. The positive relation between the degree of sales specialization of companies and their economic performance as put forward in hypothesis 3 could also not be confirmed. Instead of the expected positive effect we find a significant negative relationship between sales specialization and economic performance. Also, the expected positive relation between related M\&As and economic performance as suggested by hypothesis 4 could not be established. However, the inverse relationship between the concentration of strategic technology alliances of companies in data processing and the economic performance of companies as put forward by hypothesis 5 was confirmed by our analysis.

From the control variables only size of companies seems to have a significant, albeit negative, impact on corporate performance. The effects of labour productivity and internationalization on economic performance turn out to be not significant. 


\section{DISCUSSION}

The results of the analysis as described above seem to merit a more elaborate discussion. One of the main findings is that high rates of technological specialization are positively related to the economic performance of the companies in our sample (see hypothesis 1). The cumulative and path dependent character of technological knowledge (Dosi, 1988; Nelson and Winter, 1982) seems to favour a strong and coherent technology base (Teece et al, 1994; Robin and Wiersema, 1995; Henderson and Cockburn, 1994). Although path dependency, at first sight, seems to be a handicap for rapid technological progress because it limits the options open to companies, it often turns out to be an essential condition for the effective development of a certain technology. Due to this particular character, technological change can rapidly expand technological frontiers while it is concentrated on a continuous process of relatively small changes in separate component parts with individual research projects focusing on improvements in small elements of the technology. The complex character of modern technology and the difficulties associated with the transfer of technological knowledge seems to favour internal development instead of external competence appropriation by arm's length transactions, M\&As or strategic alliances. This is in line with our findings on the effects of external competence appropriation and with hypothesis 5. Our findings suggests that strategic technology alliances cannot be considered as effective vehicles for the acquisition of core competences, but instead should be used to 
complement endogenous capabilities (see also Hagedoorn 1993 and 1995; Harrigan, 1985; Mowery, 1988). Because of the globalization of markets, the increasing complexity of technologies, rapid technological changes and the increasing costs of $\mathrm{R} \& \mathrm{D}$, firms are no longer able to monitor all the technological developments that are important for their core markets. Strategic technology alliances enable companies to monitor several technological developments and at the same time, let them concentrate on a few, most promising, projects internally. If certain technologies turn out to be less successful then cooperative agreements can be terminated with only a relatively small loss. The importance of alliances as monitoring devices is in accordance with the findings of Hagedoorn (1995) who found that only a small share of the strategic technology linkages of industry leaders are found in their core business.

In that context we can also point at a major problem associated with M\&As that occurs if a company does not have an already sufficiently developed level of technological knowledge in a specific field. Then it turns out to be extremely difficult to absorb externally acquired knowledge into the existing technological core. It is often noted that a firm's absorptive capability is to a large degree dependent on the degree of knowledge in a specific field (Dodgson, 1989; Cohen and Levinthal, 1990; Levinthal, 1994). Therefore we might argue that if the core of a company's technology base is not sufficiently adapted to the new technology, then the absorption of newly acquired external technological knowledge within the 
technological core of a company is very difficult. This may also explain why many M\&As are not very successful in generating improved economic performance.

Given the importance of a specialized core knowledge base (see hypothesis 1), and considering previous research on diversification (Wernerfelt \& Montgomery, 1986; Varadarajan and Ramanujam, 1987; Capon et al., 1988; Ramanujam and Varadarajan, 1989; Harrison et al., 1993) we would also expect to find a positive relation between the degree of sales specialization of companies and their economic performance. Our study, however, indicates a negative relationship between the degree of sales specialization and the economic performance of the companies in our sample. The positive combination of a specialized and coherent technology base and diversified sales seems to suggest that the internally generated technological core competences can be applied beyond the traditional data processing industry. This is in line with the increased recognition that technological convergence is one of the major driving forces of technological and economic developments in the data processing market (Business Week, May 25th, 1992, pp. 69-71; Forester, 1993; Georghiou et al., 1986; de Jonquieres, 1989; Duysters, 1996). For a very long time technological development in the various information technology markets has followed very distinct trajectories. Today, the basic design parameters which form the core of technological regimes (Georghiou et al., 1986) have become increasingly similar, not only in terms of the material properties but also with respect to the manufacturing process involved. Technological 
convergence is therefore gradually removing the sectoral boundaries between the various information technology industry segments. The pervasive effect of microelectronics and software can be found to drive convergence between virtually all the major information technology markets: consumer electronics, broadcasting, instrumentation, military electronics, software, data processing and telecommunications. The ability to achieve economies of scope for many crucial products is founded on a common technological knowledge base which also explains the higher level of performance of diversified firms in the data processing industry.

\section{CONCLUSIONS}

Research on the importance of core competence building within companies in order to improve our understanding of the differences in the economic performance of individual companies has only recently emerged as an important issue within strategic management. This paper merely explores some of the crucial questions related to this issue, while it is limited to only one industrial sector, albeit a large and also a very strategic sector. Future research will have to focus on both a larger number of industrial sectors and explore the usefulness of other indicators for understanding core competences.

A major conclusion for the analysis of the role of core competences in this high-tech sector is that a specific set of endogenous technological core capabilities 
is needed to generate performance differentials. Technological specialization in terms of established and protected capabilities and a proven track record, for instance through a strong patent position, appears more important than the input of R\&D efforts as such. Also, the external appropriation of competences, for instance through M\&As and strategic technology alliances, does not seem to be an easy solution through which companies can improve their existing capabilities. 


\section{REFERENCES}

Acs, Z.J. and D.B. Audretsch (1989). 'Patents as a Measure of Innovative Activity', Kyklos, 4: 171-80.

Ansoff, I. and E. McDonnell (1990). Implanting strategic management, PrenticeHall, New York.

Auster, E. R. (1992). 'The relationship of industry evolution to patterns of technological linkages, joint ventures, and direct investment between U.S. and Japan', Management Science, 38, pp. 778-792.

Archibugi, D. (1992). 'Patenting as an Indicator of Technological Innovation: A Review', Science and Public Policy, 6: 357-8.

Barney, J.B. (1986). 'Strategic factor markets: expectations, luck, and business strategy', Management Science, 32, pp. 1231-1241.

Cantwell, J. and C. Hodson (1991). 'Global R\&D and UK competitiveness', in M. Casson (ed.), Global Research Strategy and International Competitiveness, Blackwell, Oxford.

Capon, N, J.M. Hulbert, J.U Farley and L.E. Martin (1988). 'Corporate Diversity and Economic Performance: The Impact of Market Specialization', Strategic Management Journal, 9, pp. 61-74.

Caves, R.E. (1982). Multinational enterprise and economic analysis, Cambridge University Press, Cambridge.

Cohen, W.M., R.C. Levin and D.C. Mowery (1987). Firm size and R\&D intensity: re-examination, Journal of Industrial Economics, 35, pp. 543-65.

Cohen, W.M and R.C. Levin (1989). 'Empirical Studies of Innovation and Market Structure', in R. Schmalensee and R.D. Willig, Handbook of Industrial Organization, Volume II, Elsevier Science Publishers, New York.

Cohen, W.M and D.A. Levinthal (1990). 'Absorptive Capacity: A New Perspective on Learning and Innovation', Administrative Science Quarterly, 35: 128-52. 
Davis, E. and J. Kay (1990). 'Assessing corporate performance', Business Strategy Review, 1, pp. 1-17.

Dodgson, M (1989). Technology Strategy and the Firm, Management and Public Policy, Longman, London.

Dosi, G. (1984). Technical change and industrial transformation, Macmillan, London.

Dosi, G. (1988). 'Sources, Procedures, and Microeconomic Effects of Innovation', Journal of Economic Literature, 26, pp. 1120-1171.

Dosi, G. and L. Orsenigo (1988). 'Coordination and Transformation: An Overview of Structures, Behaviours and Change in Evolutionary Environments', in Dosi et al. (eds), Technical Change and Economic Theory, Pinter Publishers, London.

Dunning, J.H. (1993), Multinational enterprises and the global economy, AddisonWesley, Wokingham.

Dunning, J.H. (1995). 'Reappraising the eclectic paradigm in an age of alliance capitalism', Journal of International Business Studies, 26, pp. 461- 491.

Duysters, G. (1996). The Dynamics of Technical Innovation: The Evolution and Development of Information Technology, Edward Elgar, Cheltenham.

Forester, T. (1993). Silicon Samurai: How Japan conquered the world's IT industry, Blackwell publishers, Cambridge, MA.

Freeman, C. (1982). The economics of industrial innovation, Pinter Publishers, London.

Gartner Group, 1994, Yardstick Top 100 Worldwide, Gartner Group, Stanford, CT. Georghiou, L., J.S. Metcalfe, M. Gibbons, T. Ray and J. Evans (1986), PostInnovation Performance: Technological Development and Competition, Macmillan, New York. 
Griliches, Z. (1990). 'Patent Statistics as Economic Indicators: A Survey', Journal of Economic Literature, 28, pp. 1661-797.

Hagedoorn, J. (1993). 'Understanding the rationale of strategic technology partnering: inter-organizational modes of cooperation and sectoral differences', Strategic Management Journal, 14, pp.371-385.

Hagedoorn, J. (1995), 'A note on international market leaders and networks of strategic technology partnering', Strategic Management Journal, 16, pp. 241250.

Hagedoorn, J. and J. Schakenraad (1994). 'The effect of strategic technology alliances on company performance', Strategic Management Journal, 15, pp.291-311.

Hamel, G. and C.K. Prahalad (1994). Competing for the future, Harvard Business School Press, Boston, MA.

Harrigan, K.R. (1985). Strategies for joint ventures, Lexington Books, Lexington. Harrison, J.S., Hall, E.H. and R. Nargundkar (1993). 'Resource Allocation as an Outcropping of Strategic Consistency: Performance Implications', Academy of Management Journal, 36, pp. 1026-1051.

Haspeslagh, P. and D. Jemison (1991). Managing acquisitions: creating value through corporate renewal, Free Press, New York.

Henderson, R. and I. Cockburn (1994). Measuring competence: exploring firmeffects in pharmaceutical research, Strategic Management Journal, 15, Special Issue Winter, pp. 63-84.

Hoskisson, R., R.A. Johnson and D.D. Moesel (1994). 'Corporate divesture intensity in restructuring firms: effects of governance, strategy, and performance', Academy of Management Journal, 37, pp. 1207-1251.

Hoskisson, R. and M.A. Hitt (1994). Downscoping - how to tame the diversified firm, Oxford University Press, Oxford. 
IDC (1988). The Computer Industry Report, December 9, Vol. 24, no 11-12

Jonquières de G. (1989), The Deadly Mirage of Convergent Technology, Financial Times, 24 July.

Klevorick, A.K., R.C. Levin, R.R. Nelson, and S.G. Winter (1995). On the sources and significance of interindustry differences in technological opportunities, Research Policy, 24, pp. 185-205.

Kogut, B. (1991), 'Joint ventures and the option to expand and acquire', Management Science, 37, pp. 19-33.

Levinthal, D.A. (1994). 'Surviving Schumpeterian Environments: An Evolutionary Perspective', in J.A.C. Baum and J.V. Singh (eds), Evolutionary Dynamics of Organizations, Oxford University Press, New York.

Malerba, F., S. Torrisi, and N von Tunzelmann (1990), The Computer (Hardware and Software) Industry, Report for the UNDP, December

Markides C.C. and P.J. Williamson (1994). 'Related diversification, core competences and corporate performance', Strategic Management Journal, 15, Special Issue Summer, pp. $\quad$ 149-165.

Meeks, G. (1977). Disappointing marriage: a study of the gains from merger, Cambridge University Press, Cambridge.

Milgrom, P and J. Roberts (1992). Economics, Organization and Management, Prentice-Hall, Englewood Cliffs, NJ.

Mowery, D.C. (ed.) (1988). International collaborative ventures in U.S. manufacturing, Ballinger, Cambridge.

Mowery, D.C., J.E. Oxley and B.S. Silverman (1995). Firm Capabilities, Technological Complementarity, and Interfirm Cooperation, Paper prepared for the conference on Technology and the Theory of the Firm,University of Reading, May 14-16. 
Nelson, R. and S. Winter (1982). An evolutionary theory of economic change, Harvard University Press, Cambridge, MA.

Nelson, R. (1991). 'Why do firms differ, and how does it matter?', Strategic Management Journal,12, pp. 61-74.

Odagiri, H. and T. Hase (1989), 'Are mergers and acquisitions going to be popular in Japan? An empirical study', International Journal of Industrial Organization, 7, pp. 49-73.

Osborn, R.N. and C.C. Baughn (1990). 'Forms of interorganizational governance for multinational alliances', Academy of Management Journal, 33, pp. 503519.

Patel, P. and K. Pavitt (1991), 'Large firms in the production of the world's technology: an important case of ' non-globalisation', Journal of International Business Studies, 22, pp. 1-21.

Pavitt, K. (1988). 'Uses and Abuses of Patent Statistics', in A.F.J. van Raan, Handbook of Quantitative Studies of Science and Technology, Elsevier, Amsterdam.

Porter, M.E. (1987). 'From competitive advantage to corporate strategy', Harvard Business Review, May-June, pp.43-59.

Ramanujam, V and P. Varadarajan (1989). 'Research on Corporate Diversification: A Synthesis', Strategic Management Journal, 10, pp. 523-551.

Ravenscraft, D.J. and F.M. Scherer (1987). 'Life after takeover', Journal of Industrial Economics, 36, pp. 147-157.

Rees, W. (1990). Financial Analysis, Englewood Cliffs(NJ), Prentice Hall.

Robins, J. and M.F. Wiersema (1995), A resource-based approach to the multibusiness firm: empirical analysis of the portfolio interrelationships and corporate financial performance, Strategic Management Journal, 16, pp. 277-299. 
Rumelt, R.P. (1974). Strategy, Structure, and Economic Performance, Division of Research, Harvard Business School, Boston, 1974.

Rumelt, R.P. (1984). Toward a strategic theory of the firm, in R. Lamb (ed.), Competitive strategic management, Englewood Cliffs(NJ), Prentice Hall, pp. 556-570.

Teece, D.J. (1982). 'Towards an economic theory of the multiproduct firm', Journal of Economic Behavior and Organization, 3, pp. 39-63.

Teece, D.J., R. Rumelt, G.Dosi and S.G. Winter (1994). 'Understanding corporate coherence - theory and evidence', Journal of Economic Behavior and Organization, 23, pp.1-30.

Varadarajan, P. And V. Ramanujam (1987). 'Diversification and performance: A reexamination using a new two-dimensional conceptualization of diversity in firms', Academy of Management Journal, 30, pp. 380-393.

Wernerfelt, B. (1984). 'A resource-based view of the firm', Strategic Management Journal, 5, pp. 171-180.

Wernerfelt, B. (1995). 'The resource-based view of the firm: ten years after', Strategic Management Journal, 16, pp. 171-174.

Wernerfelt, B and C.A. Montgomery (1986), 'What is an attractive industry?', Management Science, 32, pp. 1223-1230. 
Table 1 Regression estimates of the influence of core competences and other key variables on company performance, $n=61$

\begin{tabular}{|l|l|l|}
\hline Variable & Beta & T \\
\hline Constant & & $2.137^{* *}$ \\
\hline Technological specialization & 0.748 & $1.87^{*}$ \\
\hline Data processing R\&D & -0.127 & -0.77 \\
\hline Specialization & -0.516 & $-2.21^{* *}$ \\
\hline Mergers and acquisitions & -0.105 & -0.63 \\
\hline Strategic technology alliances & -0.283 & $-1.7^{*}$ \\
\hline Size & -0.452 & $-2.1^{* *}$ \\
\hline Productivity & 0.107 & 0.671 \\
\hline Internationalization & -0.006 & -0.043 \\
\hline
\end{tabular}

" $\mathrm{p}<0.10$

$* * \mathrm{p}<0.05$

$R^{2}=0.374 \quad$ Adj $R^{2}=0.227 \quad$ Std $E r=0.082$

$\mathrm{F}=2.540 \quad$ Sign. $\mathrm{F}=0.0276$ 


\section{Annex I List of data processing companies in the analysis}

3Com

Acer

Alps Electric

Amdahl

Apple

AST Research

AT\&T

Canon

Cisco Systems

Commodore

Compaq

CompuAdd

Computervision

Conner

Control Data Systems

Cray Research

Data General

Dell

Digital Equipment

Fujitsu

Groupe Bull

Hewlett-Packard

Hitachi

IBM

Intel

Intergraph

Lexmark

Lockheed

Mannesmann (DEC after 1990)

Matsushita

Maxtor

Memorex-Telex

Mitac

Mitsubishi

Motorola

NEC

Nihon Unisys

Northern Telecom

NTT

Oki

Olivetti

Philips Group

Quantum

Racal

Ricoh

Seagate

Seiko Epson

Siemens

Silicon Graphics

Sony

Storage Tech

Stratus

Sun Microsystems

Tandem

Tandy

Texas Instruments

Toshiba

Unisys

Wang

Wyse
USA

TAIWAN

JAPAN

USA

USA

USA

USA

JAPAN

USA

USA

USA

USA

USA

USA

USA

USA

USA

USA

USA

JAPAN

FRANCE

USA

JAPAN

USA

USA

USA

USA

USA

GERMANY

JAPAN

USA

NETHERLANDS

TAIWAN

JAPAN

USA

JAPAN

JAPAN

CANADA

JAPAN

JAPAN

ITALY

NETHERLANDS

USA

UK

JAPAN

USA

JAPAN

GERMANY

USA

JAPAN

USA

USA

USA

USA

USA

USA

JAPAN

USA

USA

TAIWAN 


\section{Notes}

1.Net income is often disturbed by accounting practices and is more sensible to temporary gains and losses (due to e.g. selling of plants), interest payments etc. Other measures of performance are often more subjective and can be used by management to influence bottom-line earnings figures (Rees, 1990)

2.Based on previous research (Hagedoorn and Schakenraad, 1994) we assumed that companies from different regions of the Triad, i.e. the USA, Japan and Europe, will have different levels of profitability or at least different profit strategies that make it necessary to control for the national background of companies. However, it turned out during the statistical analysis that dummies for national differences were closely correlated with the structural and strategic differences of companies based in a specific region.

3. The Gartner group (1994) estimates that their sample of the leading 100 data processing companies account for over 90 percent of the worldwide market. The firms in our sample cover more than 85 percent of the revenues in the Gartner Group sample. This implies that our sample accounts for more than $75 \%$ of the total data processing world market. 